\title{
GEOGRAPHICAL ASPECTS OF CRIME RESEARCH
}

\author{
Urazimbetova Yulduzkhan Haydarovna ${ }^{1}$, Turdymambetov Izimbet $^{2}$ \\ ${ }^{1}$ Basic Doctoral Student \\ ${ }^{2}$ Scientific Adviser,Doctor of Geographical Sciences \\ Karakalpak State University named after Berdakh \\ The Republic of Uzbekistan
}

Article DOI: https://doi.org/10.36713/epra9168

DOI No: 10.36713/epra9168

\begin{abstract}
ANNOTATION
The article discusses the main geographical aspects of the study of crime. The geographic aspects of the study of crime allow for the transition to the study of delinquency and crime as a mass social and social phenomenon with its characteristic geographical, quantitative and qualitative characteristics and patterns.
\end{abstract}

KEYWORDS: geocriminogenic situation, region, territory, system, offenses, regularity.

The analysis of the territorial aspects of crime is synthetically reflected in such a category as the geocriminogenic situation. The entire system of generation and the state of crime determines the geocriminogenic situation in the country or region.

The geocriminogenic situation, in turn, becomes a catalyst for crime, in particular, enhancing the geocriminogenic potential of the territory. Crimes, as manifestations of unlawful behavior, are the object of study in such an area of social geography as the geography of crime.

In the work, the geography of crime is defined as a branch of social geography that studies the territorial differentiation of offenses and the relationship between geographical conditions and the structure, level and nature of crime within territorial systems of various taxonomic rank [6].

The geographic aspects of the study of crime allow for the transition to the study of delinquency and crime as a mass social and social phenomenon with its characteristic geographical, quantitative and qualitative characteristics and patterns.

At the same time, the region acts as a territorial social system in which the specificity of the interaction of the natural environment and functionally related subsystems of production, settlement, infrastructure and life of the population itself determines the territorial heterogeneity of social, incl. criminogenic processes and becomes factors in the formation of crime $[1,2,6]$.

In particular, the first studies, taking into account the territorial aspects of the study of crime, belong to the French criminologist A.M. Harry and the Belgian sociologist A. Kettle (1833-1835).

The first scientific articles on the geography of crime in the Republic of Uzbekistan, territorial aspects of types of crime, the geocriminogenic situation were published by A.S. Soliev and his students. In 2006, under the supervision of professors A. Soliev, A. Kayumov defended his dissertation on the topic "Socio-geographical aspects of crime in Uzbekistan" [5].

As the subject of criminological analysis of crime in the regions, we consider crime in certain territories, its state, level, structure, dynamics, territorial prevalence or geography, regional differences.

The geography of crime is the spread of crime in a certain territory over a certain period of time. The aggregate information on the above-mentioned 
Volume: 9 | Issue: 11 | December 2021 | Journal DOI: 10.36713/epra0713 | SJIF Impact Factor (2021): 8.047

indicators in specific territories is defined by the generalizing term regional characteristics of crime.

The analysis of these features makes it possible to establish the patterns of occurrence and existence of crime in regions of different socio-economic, sociocultural characteristics, to single out the general and special in the latter [1,2]. The analysis of regional characteristics of crime is a complex, multifaceted, but at the same time the most complete, accurate and systematic analysis of crime. It allows to reveal not only the territorial specifics of crime in relation to homogeneous territorial-spatial systems, but also to reveal its individual characteristics in comparison with other regions.

The main task of regional crime analysis is: - in the study and identification of general indicators of crime in the regions, as the objects of analysis, its state, level, structure, dynamics, territorial prevalence (geography), characteristics of certain types of crime in the regions;

- identification of trends and patterns of general crime and its types; identifying similar and distinctive features of common crime and its types between regions.

To establish the objective laws of crime, the study of crime in the regions should be carried out in dynamics for at least 10 years.

As indicators, it is necessary to study the average indicators that reflect the level, structure and dynamics of crime in the studied territories. After analyzing the average absolute or relative indicators of crime, it is advisable to conduct a rating and cluster analysis in order to group regions according to the degree of criminal infestation of territories and to identify the degree of stability of criminological signs.

An important source of information for regional analysis is the data contained in the state statistical reporting on the state of crime.

Regional analysis of crime has inexhaustible possibilities for identifying general, special and individual qualities that characterize crime in different regions.

To obtain a comprehensive picture of the relationship between the state of crime in different regions, it is important to use methods of mathematical statistics, such as correlation and regression analyzes, principal component analysis, etc. During the conduct of criminological research in general and during the studied regional differences in crime in particular, dynamic and statistical methods are usually used [2,3].

The relatively stable patterns of the spatial distribution of crime, discovered in dynamics over a number of years, are the basis for compiling appropriate maps, diagrams, diagrams, etc.
This process is of particular importance from the standpoint of simplifying the analysis and perception of a significant amount of information. In science, these actions are called graphical methods. In its most general form, graphic methods are usually understood as a set of methods for visual representation and generalization of digital information using various kinds of geometric shapes, lines, drawings, conventional signs, schematic maps, tables and explanatory inscriptions to them $[1,2,4]$. At the same time, the most convenient visualization method used in the analysis and study of crime in the region is the mapping method. The essence of the mapping method is that certain indicators of crime are plotted on the map. Each individual map is drawn up by entering on it one or another quantitative or qualitative indicator of crime or a certain social, economic or demographic parameter of the region.

After drawing up a set of maps with the entry on them of the territorial differences of certain processes, you can get a holistic idea of the territorial distribution of crime and the factors that determine it.

Thus, the geographical aspects of the study of crime makes it possible to study delinquency and crime as a social and social phenomenon with its characteristic geographical, quantitative and qualitative characteristics, as well as patterns.

\section{LITERATURE}

1. Babaev M.M. Demographic Processes and Problems of Territorial Differences in Crime // Issues of Combating Crime. - Issue. 21.-- 2014. -P. 3-4 4 .

2. Babenko A.N. Regional crime system: its place in the general crime system and some patterns of functioning ...

3. Kuzovatova, KP Some problems of the geography of crime on the territory of the Russian Federation // Young scientist. - 2017. - No. 47 (181). - S. 121123.

4. Salakhova V.B., Lobzhanidze A.A., Goncharova E.M. Geographic factors of the dynamics of juvenile delinquency in Russia // № 2/2018 Bulletin of the Moscow University of the Ministry of Internal Affairs of Russia

5. Komilova N. Q. Maxmudov B.Kh. o'g'li, Farg'ona viloyatida jinoyatchilik turlari va hududiy tafovutlari // geography: nature and societ // №4 (2020) DOI http://dx.doi.org/10.26739/2181-08342020-4 $38-43$

6. Sikach K, Yu. Geographic factors of the dynamics of crime in Ukraine // Dissertation for the degree of candidate of geographical sciences. - Simferopol 2016 